\title{
Bankside trees and shrubs - specifics of the proposal for the vegetation arrangement
}

\author{
Miloslav Šlezingr ${ }^{1,2}$ * \\ ${ }^{1}$ Department of Landscape Management, Mendel University in Brno, Zemědělská 3, 61300 Brno, \\ Czech Rep., \\ ${ }^{2}$ University of Technology, Faculty of Civil Engineering, UVST Brno, Žižkova 17, 60200 Brno, \\ Czech. Rep.
}

\begin{abstract}
Bankside trees and shrubs are an important element in landscape enhancement. Within stream regulation, we should try to propose necessary interventions to the river profile and its closest surroundings with maximum respect for existing vegetation. Having carried out technical adjustments, it is necessary to propose, in liaison with competent specialists, and to provide for the implementation of new planting, or reconstruction of riparian and accompanying stands. The planting of, and the consequential care for, bankside trees and shrubs should not be underestimated as unplanted areas within natural succession become overgrown with self-seeding species whose unsuitable location and species structure may impair the stability of slopes, flow ratios in the riverbed and, even in aesthetical terms, they do not have to necessarily make a good impression.
\end{abstract}

\section{Introduction}

If we consider tree species growing on banks, it is important to notice the effect of the underground and aboveground parts. The root system grows through the soil profile and binds soil particles, thus reinforcing riverbed banks. Roots also grow into the zone of continuous flooding where they are a sought-after refuge for water fauna. The aboveground parts of plants relieve the pressure of running water, protect the banks against the direct effects of waves, the drifting of ice and in combination with nonliving reinforcing structures they act as long-term, durable and reliable stabilisation of banks. Protection against water flowing into the stream from adjacent land is very important, too. Banks may also be damaged in rainstorms when runoff is concentrated into one or more main currents, or when water flows back into the riverbed after overflowing onto the flood plain [6, 7].

By stabilising banks through means of grassland in combination with tree species, we can prevent riverbed banks from being damaged by erosion rills that can have a very unfavourable impact on the stability of riverbed slopes [1].

\footnotetext{
*Corresponding author: slezingnode.mendelu.cz
} 
The pre-condition for self-cleanability to develop, is a sufficiently aerated water stream and the presence of organisms in the water. Organisms colonising uneven places on the bottom, roots penetrating into the stream, parts of plants, etc., participate, to a maximum extent, in the removal of organic pollution in the stream. It is riparian vegetation, its surface and underground parts that have a considerable share in the enhancement of selfcleanability of water streams.

A direct incidence of sunrays on the water surface causes the intensive warming of water in riverbeds. Since the intensity of sunshine is highest in the summer months when the water level is also very low, water flora grows more. Irrigation channels and shallow reservoirs are most endangered. The final effect of a fast growth of hydrophytes in warm water, well provided with nutrients from the adjacent agricultural land, may be an increasing oxygen deficit with all its unfavourable consequences for fish in the reservoir (pond). In addition, it should be emphasised that an overgrown riverbed does not have to be capable of higher flow in the case of rainstorms, thus causing a flood, albeit only a local one $[3,6]$.

An increased occurrence of hydrophytes in the riverbed results in increased bottom roughness and a lower flow profile. The speed of running water reduces and, consequently, more particles are deposited. Especially smaller streams with a minor bottom slope are endangered. By means of hydrophytes, such deposits are stabilised and the flow profile gradually reduces, increasing the risk of overflows.

Appropriate bankside trees and shrubs, especially with smaller streams, prevent excessive access of direct light, partially shading the surface and very effectively preventing conditions suitable for the rapid growth of weed hydrophytes.

This is an example of the importance of vegetation on the riverbanks.

\section{Materials and methods}

In the following, we will focus on the specifics of the proposal for the vegetation arrangement. We proceed from long-term studies and observations [5, 6].

To design suitable riparian and accompanying stands, it is important to understand the division of riparian zones according to the best prospering types of vegetation - fig. 1:

profundal zone: a continuously flooded part of banks, colonised by freely floating, immersed, rooted or not - duckweed, pondweed etc.

sublitoral zone: it is often called the reed zone - reed, calamus, flowering rush and others.

eulitoral zone: a wide range, in lower parts knotweed, reed, cattail flag, near the surface soft tree species - willow, alder, poplar

supralitoral zone: above the level of the design surface, rare flooding, area of accompanying stands of English oak, ash, maple, lime tree... 


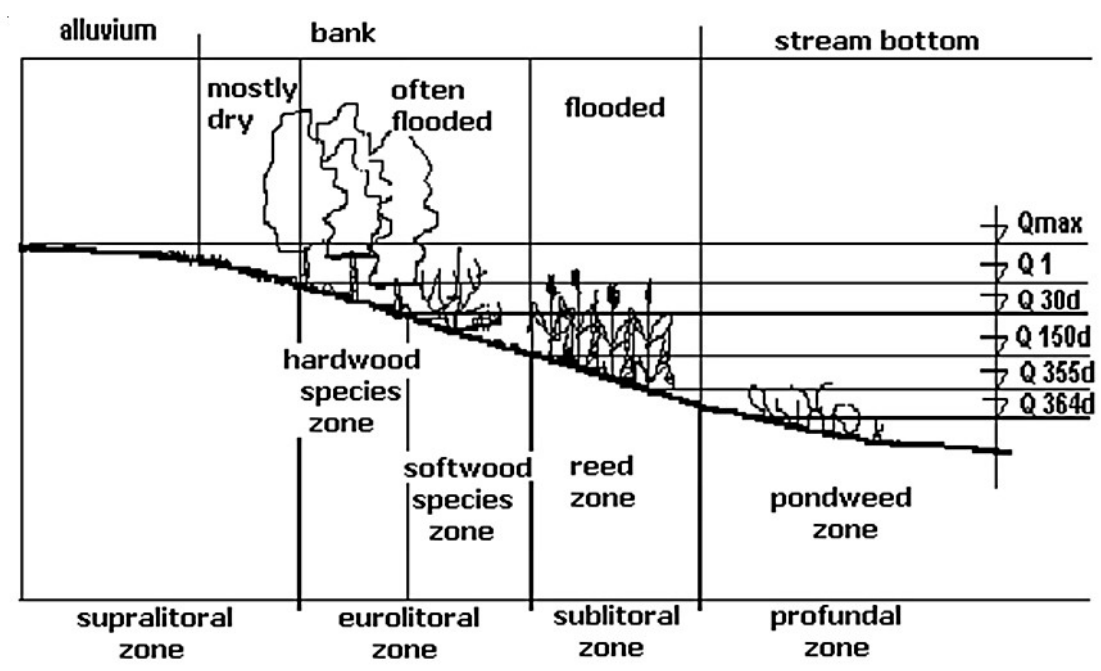

Fig. 1. Riparian vegetation arrangement (Q.....water level) [6].

\section{Generally Valid Recommendations for a Suitable Design of Accompanying Vegetation [6]:}

1. To achieve a quality riparian or accompanying stand, it is advisable to leave part ofindigenous stands, even if they are less suitable, possibly groups of fully-grown tree species, and to carry out the new planting in relation to them and under their protection.

2. Species for new planting shall be selected with a view to their future prevailing function, in particular taking into consideration whether they function as an accompanying stand (planting behind the riverbed bank line, on berm slopes as a maximum) or as a riparian stand (planting within the stabilisation of the riverbed and creating a direct relationship between the stand and the stream within the flow profile, on riverbed slopes). Or, especially in the case of smaller streams, a combination of both.

3. Monostichus, basically alley planting is not the most suitable solution either from an environmental or from a landscaping point of view and the value of such stands being part of the accompanying vegetation is low. In this case, we plant tree species on such side of the stream where they can partially shade the riverbed and we try to use, wherever possible, unexploited areas adjacent to the stream for additional planting which will increase the value of the accompanying vegetation.

4. Within the design of vegetation species structure, we should not forget shrubs, which have their indisputable place, and vital grassland, which is basic protection against the occurrence and development of erosion on the bank slope.

5. We propose in particular autochthonous species; other species only in special and justified cases. The planting of species unsuitable from a phytocoenological or landscaping point of view (exotic species, species more of collection importance...) may have a disturbing effect on the surrounding landscape.

6. When designing in particular riparian stands, it is necessary to realise the low reinforcing effect of young stands (this mostly does not concern sprouts). 
7. Over-aged plants, windthrows, dry plants, or plants intended to be disposed of for any other reason must be removed prior to starting the planting of newly designed species so as not to damage new young plants.

8. When newly establishing riparian stands of a regulated riverbed, first plant above the level of approx. $\mathrm{Q}_{150}$ - (eulitoral zone, soft tree species zone).

9. To plant new tree species, use only healthy, vital plants of prescribed parameters (species, plant age, minimum height of saplings...) and time-tested planting processes. To ensure better growth, provide the plants with wooden poles and protection against browsing)

10. The pre-condition for the good functioning of riparian and accompanying stands are regular examinations, tending cuts and the thinning of stands. In particular, care for stands in the first years after planting is very important.

11. When establishing or renewing streamside vegetation, always respect ownership relations and the minimum distance from parcel limits. In urban areas, follow green community vegetation in an appropriate manner.

12. The objective of planting is to create vertically distributed and diversified stands occupying the maximum space in the floodplain.

The main objective of establishing riparian and accompanying stands is the creation of a vegetation community, whose species composition best corresponds to the site conditions, with the representation of individual species approximating the stands that would occur in such conditions in natural development [5].

The optimal species composition of stands can best be determined based on phytocoenological examination. Since riparian and, in particular, area stands have the character of forest stands, it is advisable to use forest typology knowledge in designing their species composition. The basic typological unit is the forest type. Its ecological extent for species growth, optimal species composition and corresponding manners of management are defined. Since some types are very similar, they were included in the so-called forest type groups. The most important forest type groups correspond to the structure of riparian and accompanying stands according to the systematic division proposed by Mezera - Mráz -Samek [6]

The design of species structure is based on the conditions of a particular locality and especially on the composition of the indigenous species. In new plantings, nonautochthonous - non-indigenous introduced, exotic and fruit species should be eliminated.

Generally speaking, within riparian stands the most frequently used species are alder (Alnus), willow (Salix), ash (Fraxinus), maple (Acer), elm (Ulmus), poplar (Populus) etc. With respect to shrubs, the most frequent ones are in particular shrub willow (Salix), dogwood (Cornus), spindle tree (Euonymus), hawthorn (Crataegus), buckthorn (Frangula) and others.

Accompanying stands can be made up of ash (Fraxinus), maple (Acer), elm (Ulmus), lime (Tilia), hornbeam (Carpinus), English oak (Quercus robur); disseminated birch (Betula), mazzard (Cerasus avium), crane (Sorbus); in the undergrowth, for instance, privet (Ligustrum), hazelnut tree (Corylus), honeysuckle (Lonicera), and others.

To develop a detailed design of species composition, it is suitable to use materials obtained from professional literature (for instance, Dřeviny ČR - Úradníček, Maděra 2001, Vegetační doprovod vodních toků a nádrží - Šlezingr 2002 - fig 2, Břehové a doprovodné porosty vodních toků - Šimíček 1999 and others), but mainly professional advice from dendrologists, forest engineers and erudite ecologists. 


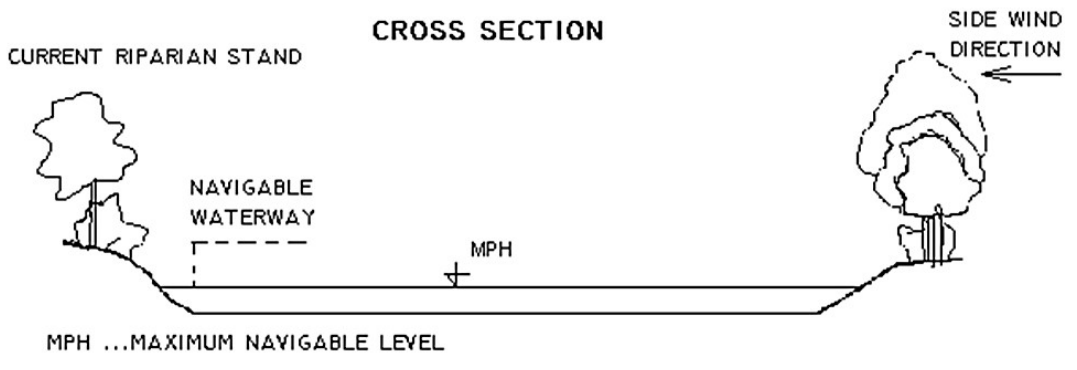

LINE PLANTING SCHEME

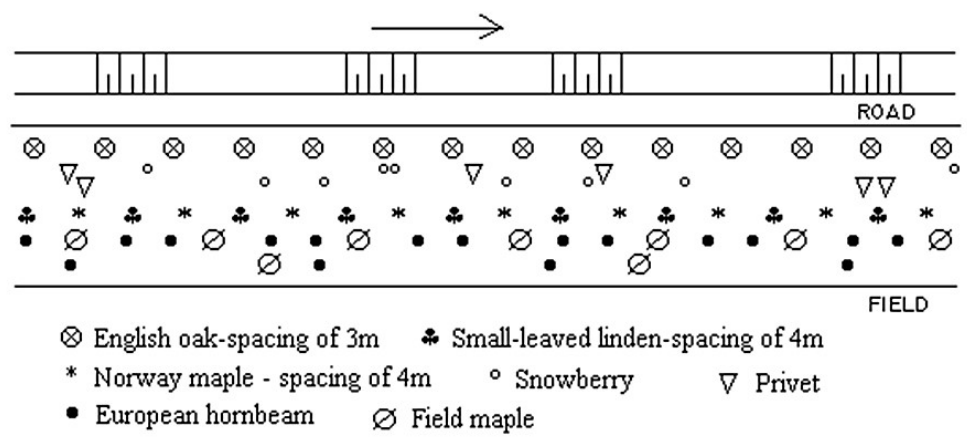

Fig. 2. Example of possible species composition and spatial arrangement of a distichous windbreak on a navigable stream bank. Hmax.pl....maximum navigable level (drawing by K. Valouchová) [6].

\section{Results}

Concerning the fulfilment of requirements of the hydrological and water function of an intervention, the design and follow-up implementation of riparian stands must respect certain principles. From the results of research and monitoring results - the project "Minimizing losses of forest and agricultural land due to erosion and abrasion processes in the landscape" reg. No. LDF_PSV_2016002, funded by IGA FFWT MENDELU Brno:

Plants growing inside the flow profile must be treated as stem stands (not coppice), with the crown above the bank line level.

To reinforce the lowest lying parts of the riverbed slope, it is optimal to place trees at a height of $0.6 \mathrm{~m}$ to $1.1 \mathrm{~m}$ above the level of average water flows in the growing season [4, $6]$.

In order to ensure that protective riparian stands successfully fulfil their function, it is suitable to carry out continuous planting, or to plant larger groups. On a concave bank, the distance between individual plants is recommended at 1.3 to $1.7 \mathrm{~m}$ in extremely curved bends, $2 \mathrm{~m}$ in bends with small curvature. Wherever the bank is direct, the suitable distance is $2 \mathrm{~m}$. In bend convexes $2 \mathrm{~m}$ greater, according to local conditions. If poplars are planted, the distance should be $4 \mathrm{~m}$ in all parts of the riverbed, also planting other species in between. Therefore, especially the protection of concave banks is essential fig 3. From the landscape enhancement and aesthetic point of view, it is important to keep vistas onto an open water surface. (Discrepancy with respect to the continuous planting requirement.) If only shrub stands are designed, it is suitable to plant them in groups, alternately on both sides of the stream (not a continuous belt on both the sides). Continuous and regular maintenance and the tending of stands is necessary.

The riverbed proposed for such adjustment should have a lined ditch bottom at least $4 \mathrm{~m}$ in width, a suitable width of berms being more than $10 \mathrm{~m}$. Riparian stands of narrower 
streams and brooks shall be treated with a view to possibly higher overgrowth of the flow profile and a higher probability of interception of possible sediments on such stands. Thus, intercepted sediments may cause local closure of the flow profile and local overflow.

The inclination of slopes should be selected at 1:2, or 1:1.5, which best suits the shape of root systems, which mostly develop at an inclination of 1:1 to 1:1.5 - fig. 4 .

Riparian stands are the most suitable complements of stone or another footing ensuring the protection of the foot of slope.

It should be pointed out that willow (especially so-called weeping willow) is not the most suitable species to be used in the flow profile as its flowing crown unfavourably regulates the water course, which results in damage to riverbed banks.

Issues related to the design of vegetative bank protection must be solved in the development of stream regulation conception, and not as a complement to the technical solution.

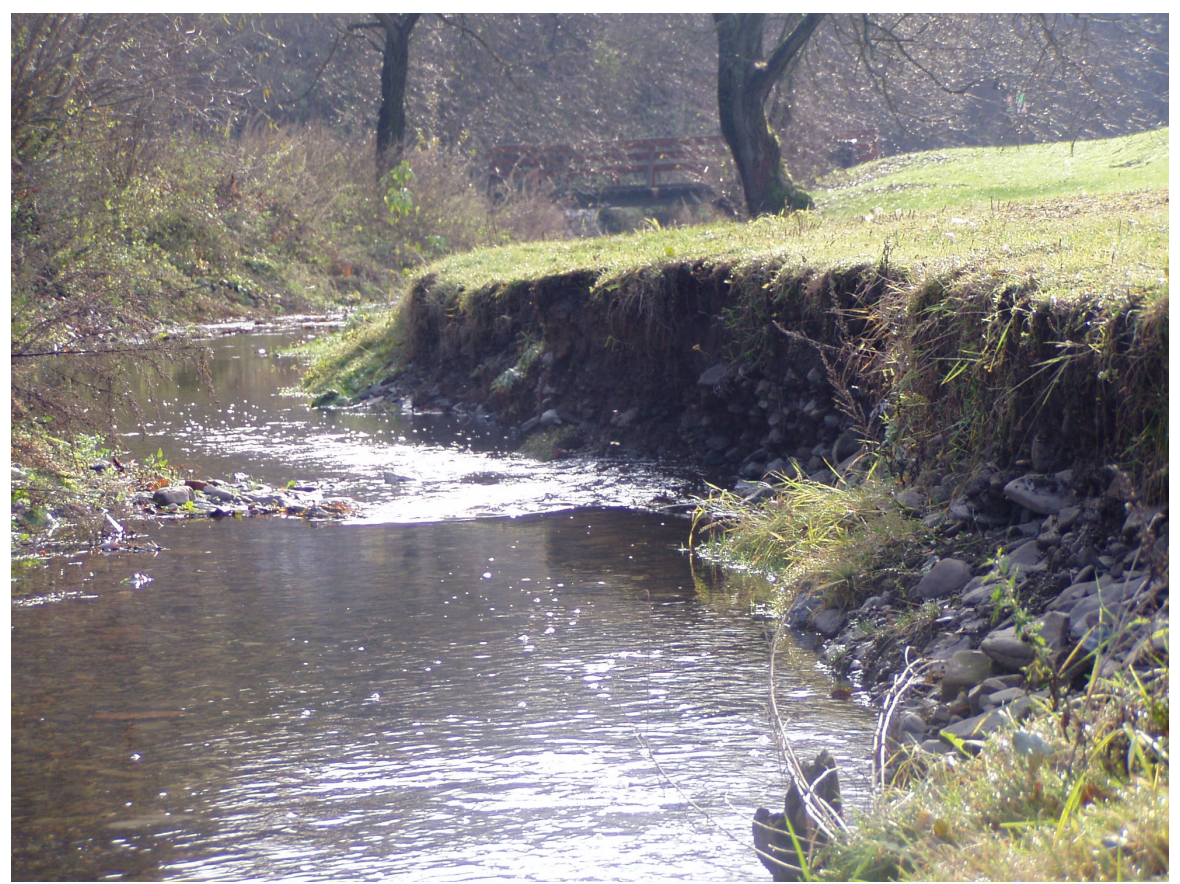

Fig. 3. Significant erosion of the river bank. Foto M.Šlezingr 2009. 


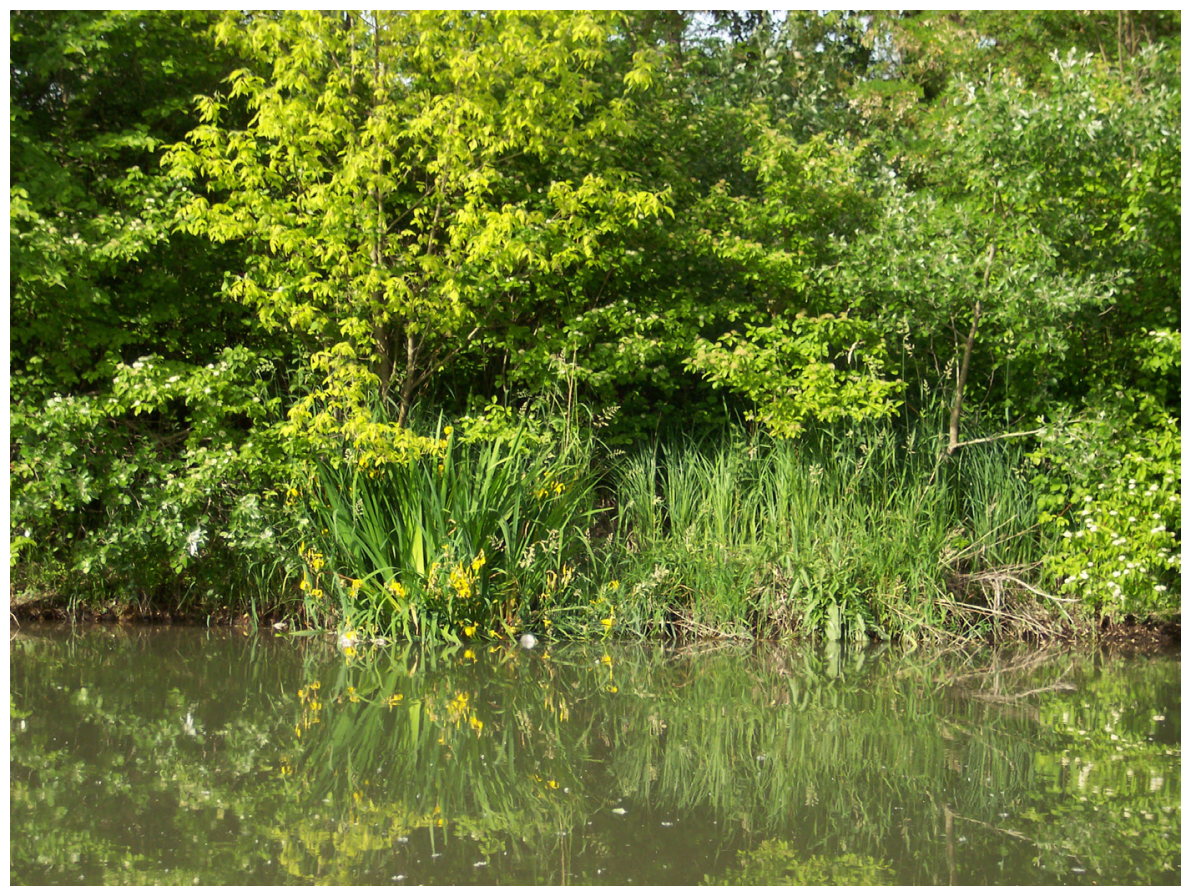

Fig. 4. Very good bank-vegetation, Maly Dunaj River, foto M.Šlezingr 2015.

\section{Conclusion}

Planting shall be started in early spring; in the case of deciduous trees (which is the case in riparian and accompanying stands) autumn is also possible. The common method is hole planting with triangular or square spacing.

Mature plants, three to six years old, are the most suitable planting material. Under extremely favourable conditions, transplanted plants two to three years old may be used. For group planting, saplings approx. $1 \mathrm{~cm}$ high, with line planting up to $1.5 \mathrm{~m}$, are sufficient. In unfavourable sites (stony, gravel ground), it is suitable to provide at least the minimum amount of humic soil.

Plants shall be shaped in planting: to ensure better growth, plants should be provided with poles; in endangered localities, plants should be protected against browsing.

In the case of species with the ability of vegetative propagation (e.g. willow, poplar, etc.), cuttings, osiers or globular plants can be used as planting material. For details on this part, see the professional literature $[4,6]$.

Bankside trees and shrubs are one of the building blocks of territorial systems of ecological stability (TSES). It is part of an ecologically balanced landscape, a form of spread green vegetation growing outside integrated forest complexes. It is created by tree species and herbs growing along streams. In relation to stream regulation, linear building along water streams etc., a lack of riparian and accompanying stands started to manifest negatively. We can say that only once it decreases, will we start to realise its indispensability in our landscape. The following paragraphs deal with the basic functions of bankside trees and shrubs. 


\section{Acknowledgement}

The article contains partial results of the research project "Minimizing losses of forest and agricultural land due to erosion and abrasion processes in the landscape" reg. No. LDF_PSV_2016002, funded by IGA FFWT MENDELU Brno.

\section{References}

1. S. Galas, A. Galas, L. Zvijakova, M. Slezingr, Environmental impact assessment proces in the V4 countries in the field of recreation and tourism, Conference on Public Recreation and Landscape Protection - with Nature Hand in Hand, Krtiny, Czech republic, Pages 45, (2013)

2. V. Ondrejka Harbulakova, M. Zelenakova, M. Rysulova, Evaluation of Ecological Flow and Concentrations of Pollutants in Selected River Basin in Eastern Slovakia, Conference: 2nd International Conference on Efficient and Sustainable Water Systems Management toward Worth Living Development (EWaS) Procedia Engineering. 162, 98-105 (2016)

3. P. Pelikán, M. Šlezingr, J. Marková, Polish Journal of Environmental Studies. 27 (2), 793-799. ISSN 1230-1485, (2018)

4. J. Markova, P. Pelikan, Public recreation and landscape protection - with nature hand in handConference: Conference on Public Recreation and Landscape Protection - with Nature Hand in Hand, 242-248, (2016)

5. Z. Poórová, Z. Vranayová, Journal of Landscape Management. 2, 24-30 (2015)

6. M. Šlezingr, L.A. Úradníček, Bankside trees and shrubs, CERM Brno 2003, 127 p,

7. M. Zelenakova, V. Ondrejka Harbul'akova, Z. Karaszova, Soil erosion risk in the catchment area of the water reservoirs, Conference on Public Recreation and Landscape Protection - with Nature Hand in Hand, pts 1 and 2 Book Series: Public Recreation and Landscape Protection, Pages: 227-232 Published: 2015

8. M. Zelenakova, V. Harbulakova Ondrejka, Z. Kárászová, Journal of Landscape Management. 2, 30-38 (2015) 